\title{
ПРАКТИКА ПРИЗНАЧЕННЯ ПОКАРАНЬ ЗА КРИМІНАЛЬНІ ПРАВОПОРУШЕННЯ, ЩО ПОСЯГАЮТЬ НА ГРОМАДСЬКУ ТА ПРИВАТНУ ПРОФЕСІЙНУ ОХОРОННУ ДІЯЛЬНІСТЬ В УКРАЇНІ
}

\author{
СИЙПЛОКІ Микола Васильович - кандидат юридичних наук, доцент, \\ доцент кафедри кримінального права і процесу Ужгородського національного \\ університету
}

DOI:10.32782/NP.2019.4.14

Стаття присвячена аналізу судової практики призначення покарань за кримінальні правопорушення, шьо посягають на громадсъку та приватну пробесійну охоронну діяльність в Україні.

Акцентовано увагу на виключній значимості детального вивчення судової практики з иъого питання для встановлення фбакту дотримання чи недотримання судом загальних та спеціальних правил призначення покарання.

Охарактеризовано загальні засади призначення покарання, якими суд зобов'язаний керуватися при призначенні покарання за кожний вчинений злочин.

У результаті здійснення аналізу практики призначення покарань за злочини, що посягають на громадсъку та приватну професійну охоронну діяльність в Україні.

Обгрунтовано, що суди повинні чітко конкретизувати ступінь впливу тієі чи іншої пом'якиуючої чи обтяжуючої обставини. Перспективним вбачається наукова розробка чітких нормативно визначених правил, якими має керуватися суд при врахуванні відповідних обставин.

Зроблено висновок, шо призначення справедливого покарання є одним з ключових принцииів кримінального закону, однією з головних изілей правосуддя та основою попередження злочинів.

Ключові слова: покарання, призначення покарання, охоронна діяльність, приватна охоронна діяльність, кримінальна відповідальність, злочини у сбері охоронної діяльносmi.
Постановка проблеми

На сьогодні в Україні досить гостро стоїть питання забезпечення безпеки особи, суспільства та держави від постійно виникаючих системних кримінальних загроз, у різних сферах життедіяльності, зокрема щодо захисту майна, забезпечення прав і законних інтересів суб'єктів господарювання та фізичних осіб; забезпечення державного контролю за здійсненням заходів з охорони майна та фізичних осіб. Забезпечення надійного захисту своїх інтересів, у першу чергу майнових, $є$ однаково актуальним як для державного, так і для приватного сектору України. За результатами досліджень, $15 \%$ громадян вважають незадовільним стан забезпечення безпеки фізичних осіб та охорони права власності та лише $10 \%$ - високим. Це негативно характеризує стан охоронної діяльності в Україні враховуючи, що ситуація в країні є криміногенною [1, с. 238]. У зв'язку з чим до діяльності з надання послуг з охорони власності та громадян залучається все більша кількість суб'єктів охоронної діяльності, вагомий сегмент серед яких займають громадські та приватні структури. Однак, законодавче врегулювання приватної охоронної діяльності на сьогодні містить певні прогалини в плані забезпечення захисту такої діяльності, в тому числі кримінально-правовими засобами. 
Метою статті $\varepsilon$ аналіз практики призначення покарань за кримінальні правопорушення, що посягають на громадську та приватну професійну охоронну діяльність в Україні, виявлення недоліків правозастосовної практики та надання пропозицій щодо їх усунення.

\section{Аналіз останніх досліджень і публікацій}

Останнім часом простежується інтенсифікація наукових досліджень щодо розширення сфери правового регулювання здійснення громадських і приватних охоронних послуг. При чому зазначене питання є актуальним не лише для галузі кримінального права, а й для адміністративного, господарського та цивільного права, якими також прямо чи опосередковано врегульовано здійснення громадської та приватної професійної охоронної діяльності в Україні.

Серед авторів, які торкались проблематики охоронної діяльності в різних ï вимірах, слід вказати О. М. Бандурка, M. I. Бачило, Д. В. Бездітко, Ю. М. Бєліков, С. Г. Гаспарян, T. С. Гончарук, К. В. Громовенко, С. П. Довбій, С. В. Ківалов, О. О. Пунда, Н. В. Устименко, С.С. Юрко, С. А. Шейфер та ін. Однак, у вітчизняній юридичній науці явно недостатньо дослідженим є питання щодо аналізу практики призначення покарань за кримінальні правопорушення, що посягають на громадську та приватну професійну охоронну діяльність в Україні. Розгляд цього питання відповідав би сучасним запитам та потребам суспільства в цьому напрямку.

\section{Виклад основного матеріалу}

Призначення покарання $є$ завершальною стадією процесу правозастосування, на якій судом вирішується питання про те, який саме вид і розмір покарання необхідно і доцільно призначити обвинуваченому/підсудному з метою його подальшого виправлення, а також запобігання вчиненню ним нових злочинів. На цій ста- дії суд зобов'язаний керуватися певними правилами або дотримуватися встановлених вимог. У теорії кримінального права ці вимоги або правила прийнято поділяти на загальні і спеціальні [2].

Аналіз практики призначення покарань за злочини, що посягають на громадську та приватну професійну охоронну діяльність в Україні, свідчить про те, що у цілому, з огляду на судову дискрецію, суди дотримуються як загальних, так і спеціальних правил призначення покарання. Так, наприклад, Печерським районним судом м. Києва затверджена угода про примирення між потерпілим особою К та обвинуваченим особою $\lambda$. Судом особу $\lambda$ визнано винним у вчиненні кримінального правопорушення - злочину, передбаченого ст. 342 ч. 2 КК України, і призначено узгоджене сторонами покарання у виді штрафу у розмірі 100 неоподаткованих мінімумів доходів громадян, що становить 1700 (тисячу сімсот) гривень. Згідно 3 вказаною угодою особа $\Lambda$ беззастережно визнав свою винуватість у вчиненні кримінального правопорушення, передбаченого ст. 342 ч. 2 КК України. Крім того, активно сприяв розкриттю злочину, щиро розкаявся в тому, що вчинив злочин, та попросив вибачення у потерпілого [3].

Приклади дотримання вимог закону щодо загальних і спеціальних засад призначення покарання за злочини і кримінальні проступки, що посягають на громадську та приватну професійну охоронну діяльність в Україні, яскраво репрезентовані й іншими судовими вироками.

Попри це, іноді під час призначення покарання за кримінальні правопорушення, що посягають на громадську та приватну професійну охоронну діяльність в Україні, суди допускають чисельних помилок. Так, при вирішенні питання про вид та міру покарання за вчинення кримінального правопорушення, передбаченого ч. 1 ст. 122 і ч. 2 ст. 342 КК України, Артемівський районний суд, відповідно до ст. 65-67 КК України, врахував ступінь тяжкості вчиненого злочину, особу 


\section{Кримінальне право, кримінальний процес та криміналістика}

винного та обставини, що пом'якшують та обтяжують покарання. Відповідно до статті 66 КК України, обставинами, що пом'якшують покарання особи А., є щиросердне каяття, повне визнання своєї вини, відшкодування завданої шкоди потерпілому. Відповідно до статті 67 КК України обставини, що обтяжують покарання, є вчинення злочину у стані алкогольного сп'яніння, рецидив злочину. 3 огляду на ступінь тяжкості вчинених особою А 3лочинів, даних про особу обвинуваченого, який задовільно характеризується за місцем проживання, раніше неодноразово засуджений, на обліку у лікаря-психіатра та лікаря-нарколога не перебуває, суд вирішив за необхідне обрати обвинуваченому особі А за ч. 1 ст. 122 КК України покарання у вигляді обмеження волі строком на 1 рік, за ч. 2 ст. 342 КК України у вигляді обмеження волі строком на 2 роки, a із застосуванням ст. 70 КК України остаточне покарання у вигляді обмеження волі строком на 2 роки, оскільки саме таке покарання є необхідним та достатнім для виправлення обвинуваченого та попередження вчинення ним нових злочинів [4].

Уявляється, що у даному випадку суд неправильно виявив і встановив окремі 3 обставин, що пом'якшують покарання. Зокрема, судом констатована перевага обставин, що пом'якшують покарання над обставинами, що його обтяжують, а також негативно характеризують винного. Насправді, це не зовсім так. Справа в тому, що повне визнання вини є змістовною характеристикою саме щиросердного каяття, а не окремою самостійною обставиною, що пом'якшує покарання. Пункт 3 постанови Пленуму Верховного Суду України № 12 від 23.12.2005 «Про практику застосування судами України законодавства про звільнення особи від кримінальної відповідальності» вказує, що щире розкаяння характеризує суб'єктивне ставлення винної особи до вчиненого злочину, яке виявляється в тому, що вона визнає свою провину, висловлюе жаль з приводу вчи- неного та бажання виправити ситуацію, що склалася [5].

Вказане безпосередньо знаходить своє підтвердження й у практиці Касаційного кримінального суду у складі Верховного Суду, який звертає увагу на те, що щире каяття як таке характеризує суб'єктивне ставлення винного до вчиненого злочину, яке полягає в тому, що він визнає свою провину, висловлює жаль з приводу вчиненого та бажає виправити ситуацію, що склалася. За наявності щирого каяття особи не обов'язковим має бути активне сприяння у розкритті злочину. Активне сприяння розкриттю злочину є окремою обставиною, що пом'якшує покарання, згідно 3 п. 1 ч. 1 ст. 66 КК. Тобто передбачені п. 1 ч. 1 ст. 66 КК обставини, що пом'якшують покарання, а саме щире каяття і активне сприяння розкриттю злочину, $\epsilon$ альтернативними, незалежними та можуть існувати відокремлено одна від одної [6]. Крім того, Касаційний кримінальний суд звертає увагу на те, що основною формою прояву щирого каяття є повне визнання особою своєї вини та правдива розповідь про всі відомі їй обставини вчиненого злочину. Якщо особа приховує суттєві обставини вчиненого злочину, що значно ускладнюе його розкриття, визнає свою вину лише частково для того, щоб уникнути справедливого покарання, ï каяття не можна визнати щирим, справжнім. Щире каяття повинно грунтуватися на належній критичній оцінці особою своєї протиправної поведінки, її осуді, бажанні виправити ситуацію, яка склалась, та нести кримінальну відповідальність за вчинене, а також зазначена обставина має знайти своє відображення в матеріалах кримінального провадження [7].

Отже, 3 вищенаведеного вироку Артемівського районного суду, якщо і вбачаються обставини, що пом'якшують покарання, то лише дві з них, зокрема, відшкодування завданої потерпілому шкоди i щиросердне каяття. Ці обставини, що пом'якшують покарання, кореспондують двом обставинам, що його обтяжують - ста- 
ну алкогольного сп'яніння і рецидиву злочину. Крім того, відомості, що характеризують особу обвинуваченого, засвідчують його виключно задовільну, а не позитивну характеристику. У зв’язку з цим, можна стверджувати, що Артемівський районний суд призначив покарання, що не відповідає загальним засадам його призначення та приписам ч. 2 ст. 65 КК України. Як наслідок, воно є занадто м'яким, з огляду на ступінь тяжкості вчиненого злочину, особу винного та обставини, що пом'якшують і обтяжують покарання. Через це уявляється, що з огляду на загальні засади призначення покарання особі А варто було б або призначити покарання у вигляді обмеження волі ближче до його максимального строку (за ч. 1 ст. $122-3$ роки; зач. 2 ст. $342-4$ роки; 3 огляду на приписи ст. 70 - 4 роки), або ближче до мінімального строку покарання у вигляді позбавлення волі (за ч. 1 ст. $122-3$ роки; за ч. 2 ст. 342 - 2 роки; $з$ огляду на приписи ст. 70 - 1 рік 6 місяців).

Випадки визнання щирого каяття і повного визнання вини як самостійних обставин, що пом'якшують покарання, при його призначенні за злочини, що посягають на громадську та приватну професійну охоронну діяльність, доволі часто зустрічається у вітчизняній судовій практиці [8]. Подібну практику навряд чи можна визнати такою, що грунтується на припиcax чинного законодавства України.

Іноді в судовій практиці трапляються випадки неправильного застосування закону під час призначення покарання за злочини, що посягають на громадську та приватну професійну охоронну діяльність, з огляду на спеціальні засади його призначення.

У доктрині кримінального права під спеціальними засадами призначення покарання пропонується розуміти передбачені законом правила призначення покарання, що відображають специфіку вчиненого кримінального правопорушення або особу, яка його вчинила, в окремому кримінальному провадженні [9].
Так, вироком Ковпаківського районного суду м. Суми від 20.05.2013 особу Ю було визнано винним у вчиненні злочинів, передбачених ч. 2 ст. 365 , ч. 3 ст. 368 КК України і призначено йому покарання:1) за ч. 2 ст. 365 КК України із застосуванням ст. 69 КК України у виді обмеження волі на строк один рік з позбавленням права займати посади, пов'язані з здійсненням функцій службової особи, строком на один рік; 2) за ч. 3 ст. 368 КК України із застосуванням ст. 69 КК України у виді обмеження волі на строк один рік шість місяців з позбавлення права займати посади, пов'язані зі здійсненням функцій службової особи, строком на два роки без конфіскації майна. На підставі ст. 70 КК України за сукупністю злочинів, остаточно призначити особі Ю покарання у виді обмеження волі на строк один рік шість місяців 3 позбавлення права займати посади пов'язані 3 здійсненням функцій службової особи строком на два роки без конфіскації майна. При призначенні особі Ю виду і міри покарання суд врахував ступінь тяжкості вчинених злочинів, особу винного та обставини, що пом'якшують та обтяжують покарання. Зокрема, судом встановлено, що особа Ю згідно зі ст. 89 КК України раніше не судимий, позитивно характеризується за місцем проживання та роботи, має на утриманні матір пенсійного віку, яка має поганий стан здоров'я, підвищеної небезпеки для оточуючих не становить, займав невисоке службове становище, його діями не було завдано великої шкоди. Ці обставини суд визнає такими, що пом'якшують його покарання. Обставин, що обтяжують покарання, суд не вбачає [10].

Згідно з ч. 1 ст. 69 КК України за наявності кількох обставин, що пом'якшують покарання та істотно знижують ступінь тяжкості вчиненого злочину, з урахуванням особи винного суд, умотивувавши своє рішення, може, крім випадків засудження за корупційний злочин, призначити основне покарання, нижче від найнижчої межі, встановленої в санкції статті 


\section{Кримінальне право, кримінальний процес та криміналістика}

(санкції частини статті) Особливої частини КК, або перейти до іншого, більш м'якого виду основного покарання, не зазначеного в санкції статті (санкції частини статті) Особливої частини КК за цей злочин. Зі змісту цієї частини статті вбачається, що суд може призначити будь-яке основне покарання, нижче від найнижчої межі, встановленої в санкції статті (санкції частини статті) Особливої частини КК, або перейти до іншого, більш м'якого виду основного покарання, не зазначеного в санкції статті (санкції частини статті) Особливої частини КК за цей злочин лише у разі: 1) наявності кількох (двох і більше) обставин, що пом'якшують покарання, а також якщо позитивні характеристики особи винного превалюють над його негативними характеристиками; 2) якщо декілька обставин, що пом'якшують покарання, істотно знижують ступінь тяжкості вчиненого кримінального правопорушення.

3 вищенаведеного прикладу судової практики вбачається, що суд, реалізуючи положення ст. 69 КК України при призначенні більш м'якого покарання, ніж передбачено законом, врахував лише обставини, що пом'якшують покарання. Навіть, якщо гіпотетично і погодитися 3 репрезентованою позицією суду, то виникає запитання: «А які ж конкретно відомості, що характеризують особу винного, були у такому уразі враховані судом під час прийняття ним рішення про застосування ст. 69 КК України? Їх врахування 6 обов'язковим для суду». 3 огляду на положення ст. 69 КК України, можна впевнено стверджувати, що врахування лише обставин, що пом'якшують покарання, ще замало для реалізації у наведеному прикладі можливості призначення більш м'якого виду основного покарання, не зазначеного в санкції ч. 2 ст. 365 і ч. 3 ст. 368 КК України. Крім того, з вищенаведеного прикладу судової практики вбачається, що суд фактично визнав обставинами, що пом'якшують покарання, ті обставини, які в дійсності такими не є. Так, навряд чи факт несудимості особи, позитивна характеристика 3 місця проживання і роботи, наявність на утриманні матері пенсійного віку, яка має поганий стан здоров'я, відсутність підвищеної небезпеки винної особи для оточуючих, зайняття ним невисокого службового становища і не завдання вчиненням вказаних кримінальних правопорушень великої шкоди, є свідченням наявності обставин, що пом'якшують покарання, навіть 3 огляду на приписи ч. 2 ст. 66 КК України. Вказані обставини, на наше глибоке переконання, є виключно тими обставинами, що характеризують особу винного. Отже, на нашу думку, законні підстави для призначення Ковпаківським районним судом м. Суми особі Ю покарання за ч. 2 ст. 365 КК України із застосуванням ст. 69 КК України у виді обмеження волі на строк один рік $з$ позбавленням права займати посади пов'язані зі здійсненням функцій службової особи строком на один рік, а за ч. 3 ст. 368 КК України із застосуванням ст. 69 КК України у виді обмеження волі на строк один рік шість місяців 3 позбавлення права займати посади, пов'язані зі здійсненням функцій службової особи строком на два роки без конфіскації майна, фактично були відсутнi.

Тут варто також звернути увагу ще i на те, що у ст. 69 КК України передбачена вимога вираховування судом під час призначення більш м'якого покарання, ніж передбачено законом, не просто обставин, що пом'якшують покарання, а виключно тих обставин, що пом'якшують покарання та, водночас, істотно знижують ступінь тяжкості вчиненого злочину. У пункті 8 постанови Пленуму Верховного Суду України № 7 від 24.10.2003 «Про практику призначення судами кримінального покарання» вказано, що у кожному випадку під час призначення більш м'якого покарання, ніж передбачено законом, суд зобов'язаний у мотивувальній частині вироку зазначити, які саме обставини справи або дані про особу підсудного він визнає такими, що істотно знижують ступінь тяжкості вчиненого злочину і впливають на 
пом'якшення покарання, а в резолютивній - послатися на ч. 1 ст. 69 КК України. При цьому необхідно враховувати не тільки мету й мотиви, якими керувалась особа при вчиненні злочину, а й їі роль серед співучасників, поведінку під час та після вчинення злочинних дій тощо [5].

У вищенаведеному прикладі судової практики вказана рекомендація вищої судової інстанція, що грунтується на приписах ч. 1 ст. 69 КК України, судом також не врахована. У наведених та цілому ряді інших прикладів судової практики складно у мотивувальній частині вироку суду віднайти вказівку на те, які саме обставини, що пом'якшують покарання, або дані про особу підсудного він визнає такими, що істотно знижують ступінь тяжкості вчиненого злочину і впливають на пом'якшення покарання.

\section{Висновки та перспективи подальших досліджень}

Аналіз судової практики в частині призначення покарань за кримінальні правопорушення, що посягають на громадську та приватну професійну охоронну діяльність в Україні, показав, що нерідкими є проблеми та помилки, пов'язані із неправильним застосуванням судом норм закону, різного трактування та недотримання основних принципів і засад призначення покарання.

При призначенні покарання суди повинні чітко дотримуватись законодавчо визначеного механізму щодо обчислення виду і розміру покарання. Призначення максимально справедливого покарання за вчинений злочин напряму залежить від якості законодавчого регулювання цього процесу та практики його застосування, i є одним з ключових принципів закону, однією з головних цілей правосуддя.

При призначенні покарання необхідним $є$ конкретизація ступеню впливу на відповідальність тієї чи іншої обставини або сукупності таких обставин (обтяжуючих або пом'якшуючих) та визначення обсягу кримінальної відповідальності, що є важливим засобом індивідуалізації покарання.

Неприпустимим $є$ формальний підхід суддів до врахування пом'якшуючих чи обтяжуючих обставин під час призначення покарання, у зв'язку з чим перспективним вбачається наукова розробка чітких нормативно визначених правил, якими має керуватися суд при врахуванні відповідних обставин, що значно звузить «межі суддівського розсуду», які є занадто розмитими, що іноді призводить до зловживання правом та суб'єктивізму, що 6 недопустимим в досягненні визначених у кримінальному кодексі країни цілей покарання.

\section{Мiтература}

1. Мислива О. О. Повноваження приватних охоронних структур: взаємодія чи протидія органам внутрішніх справ. Науковий вісник Дніпропетровсъкого державного університету внутрішніх справ. 2013.№ 2. С. 238-246.

2. Кримінальне право України: Загальна частина : підручник / B.I. Борисов,В.Я. Тацій, В.І. Тютюгін та ін. ; за ред. В.Я. Тація, В.І. Борисова, В.І. Тютюгіна. - 5-те вид., переробл. і допов. Харків: Право, 2015. 528 с.

3. Вирок Печерського районного суда м. Києва від 29.07.2013 р. № 757/15420/13к / Єдиний державний реєстр судових рішень. URL: http://reyestr.court.gov. ua/Review/32746053 (дата звернення 23.09.2018).

4. Вирок Артемівського районного суду м. Ауганська від 25.06.2014 р.№ 434/8868/13-к / Єдиний державний реєстр судових рішень. URL: http://reyestr. court.gov.ua/Review/39440099 (дата звернення 23.09.2018).

5. Постанови Пленуму Верховного Суду України у справах кримінальної спеціалізації: Збірник постанов / укл.: д. ю. н., проф. О. М. Аитвинов; д. ю. н, доц. А. М. Ященко. Харків: Константа, 2018. 320 с.

6. Постанова Верховного Суду від 07 листопада 2018 року у справі № 297/562/17 


\section{Кримінальне право, кримінальний процес та криміналістика}

(провадження № 51-329км18) / Сдиний державний реєстр судових рішень. URL: http://reyestr.court.gov.ua/Review/77870634 (дата звернення 23.12.2018).

7. Постанова Верховного Суду від 30 жовтня 2018 року у справі № 559/1037/16-к (провадження № 51-3612км18) ) / Сдиний державний реєстр судових рішень. URL: http://reyestr.court.gov.ua/Review/77654034 (дата звернення 23.12.2018).

8. Вирок Артемівського районного суда м. Ауганська від 12.04.2013 р.№ 434\2419\13-К / Сдиний державний реестр судових рішень. URL: http://reyestr. court.gov.ua/Review/30615926 (дата звернення 23.09.2018).

9. Ященко А. М. Застосування заходів кримінально-правового характеру: монографія. Харків: НІКА НОВА, 2014. 349 с.

10. Вирок Ковпаківського районного суда м. Суми від 20.05.2013 р. №1806/13629/12 / Єдиний державний реєстр судових рішень. URL: http://reyestr. court.gov.ua/Review/31286400 (дата звернення 23.09.2018).
The article is focused on the analysis of the case law about imposition of punishment for criminal offenses that encroach on public and private professional security activities in Ukraine.

Emphasis has been placed on the crucial importance of a thorough study of the case law on this issue in order to establish the fact whether the court observed or not the general and special rules on imposition of punishment as a basis for further imposition of a reasonable, justified, individualized, fair punishment.

The author has characterized general principles of imposition of punishment as legal requirements that the court is obliged to follow while imposing punishment for each committed crime.

As a result of the conducted analysis of the practice of imposing punishment for crimes that encroach on public and private professional security activities in Ukraine, it has been established that the courts, in the light of judicial discretion, adhere in most cases to both general and special rules of imposing punishment, but there are often problems and mistakes that arise from the court's misapplication of the law, its different interpretation, and its failure to comply with the basic principles and grounds of imposing punishment.

It has been substantiated that the courts should clearly specify the degree of influence of a particular mitigating or aggravating circumstance or their complex on the imposition of punishment and determination of criminal liability. In this regard the formal approach and subjectivity on the issue of mitigating or aggravating circumstances while imposing punishment are unacceptable. The scientific development of clear normative rules, which should be guided by the court, taking into account the relevant circumstances is very perspective.

It has been concluded that the courts while imposing punishment for crimes that encroach on public and private professional security activities in Ukraine, should strictly adhere to the legally prescribed mechanism for calculating the type and amount of punishment. The imposition of a fair punishment is one of the key principles of criminal law, one of the main goals of justice and the basis of crime prevention.

Key words: punishment, sentencing, security activities, private security activities, criminal liability, crimes in the field of security activities. 